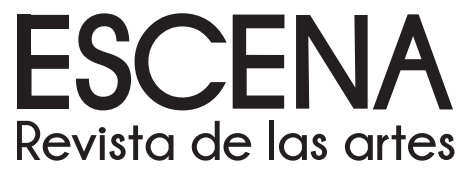

Publicación semestral. ISSN 2215-4906
Volumen 78 - Número 1
Julio - Diciembre 2018

\title{
Rolando Castellón, instalaciones y murales
}

Luis Fernando Quirós Valverde

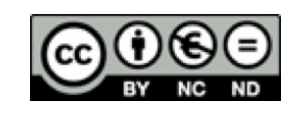

Esta obra está bajo una licencia Creative Commons Reconocimiento-No comercial-Sin Obra Derivada 


\title{
Rolando Castellón, instalaciones y murales
}

\author{
Luis Fernando Quirós Valverde ${ }^{1}$ \\ Universidad Véritas \\ Costa Rica
}

Recibido: 2 de febrero del 2017 Aprobado: 30 de enero del 2018

Decir que se conoce a Rolando Castellón -entre sus nombres, posturas, visiones, miradas- es contradictorio; aunque él es uno, no muchos, como se ha dicho por ahí. Pero, su arte si es único, sin embargo, a su vez, está en todas partes. En este ensayo lo observaremos, caminaremos con él, escucharemos las palpitaciones de su corazón, donde reside esa poética tan genuina, lo confrontaremos y comentaremos qué se ha dicho acerca de esa impresionante obra, y en especial, sobre sus murales-instalaciones, con ese lenguaje juguetón e incisivo: el arte de enaltecer los materiales.

\section{Moyo Coyatzin el instalador de muros}

A este artista se le conoce como el instalador de "muros". Pero, para ser un instalador de muros es necesario saber recolectar en el camino: recoger raíces, semillas, caparazones, piedras, papeles, cartones, maderas, estructuras, marcos, varillas, zapatos, hilos, botellas de vidrio, libros, periódicos, revistas, plantas vivas, flores secas, marcos de pochote, videos, fragmentos de concreto; todas estas son reminiscencias de la vida. Para recolectar en el camino se requiere, también, ser buen caminante. Ser caminante es sinónimo de pensar, en tanto que, al caminar se reflexiona y se encuentra. En vano sería salir a andar sin recoger nada, sin llegar a alguna conjetura acerca de la existencia y, en nuestro caso, -los artistas- teorizar sobre el arte mismo.

En muy diversos textos, me he referido a Rolando Castellón -Premio Nacional de Artes Visuales Francisco Amighetti 2016- como un recolector o catador de belleza. Esto retomando las palabras de Adriano, emperador romano en la novela histórica de Margarita Yourcenar -traducida al español por Julio Cortázar-, titulada Memorias de Adriano, en la cual se aprecia:

1 Profesor titular de Diseño Gráfico en Universidad Véritas. Pintor, posee estudios en Artes Plásticas. Correo electrónico: luquiva@gmail.com 
Quien ama lo bello termina por encontrarlo donde quiera, filón de oro en las venas más innobles, y goza, al tener en sus manos esas obras maestras fragmentarias, manchadas o rotas, un placer de entendido que colecciona a solas una alfarería que otros creen vulgar (Yourcenar, 2003, p. 22).

\section{¿Por qué un instalador de muros?}

En el año 2005, el Museo de Arte y Diseño Contemporáneo (MADC) dedicó la sala principal a una retrospectiva de su obra, curada por Ernesto Calvo. En esta se apreció un impresionante mural de Castellón en las paredes de ese espacio. Para esos años, ya había realizado otros proyectos de este género de arte, que se comentarán más adelante. También, para la Décima Bienal Centroamericana de Arte Contemporáneo, en setiembre de 2016, realizada en varias sedes de la ciudad capital San José y en la ciudad caribeña de Puerto Limón y dirigida por la crítica de arte y curadora cubana residente en Madrid, Tamara Díaz Bringas. El Museo Nacional de Costa Rica -una de las sedes del evento- albergó la muestra retrospectiva de Rolando Castellón, con la cual rindió homenaje a su amplia trayectoria. En este mismo año, el Museo de Jade y la Cultura Precolombina realizó una muestra de arte contemporáneo en su sala de exposiciones temporales titulada Conclusiones Actuales sobre el Arte Originario donde Castellón, con el pseudónimo de Moyo Coyatzin, instala "Muro de Memorias".

Por tanto, instalar muros es una vocación creativa, la cual vamos a observar, analizar y evocar en este ensayo. Pero antes, quisiera mencionar que lo conozco desde 1994, cuando Virginia Pérez-Ratton (1950-2010) nos llamó a acompañarla a fundar el proyecto del Museo de Arte y Diseño Contemporáneo (MADC), él como curador jefe y yo, como curador de diseño y jefe del departamento de documentación. Aquellos años fueron exhaustivos y de enorme crecimiento profesional. A partir del año 2000, seguimos "formando yunta" en varios proyectos expositivos hasta la actualidad, como las muestras MAYINCA (a la fecha se han realizado séis), 'atlÁntis' / centrAmérica, y la más reciente fue Mayinca Arquitéctica, montada en las salas del Centro de Investigación y Conservación del Patrimonio Nacional en 2017.

\section{Reminiscencias en el muro}

Sus recolectas de objetos vivencian los rastros de su paso, que recoge lo que encuentra, lo que atrae su mirada escudriñadora y que entreteje en un sistema mayor llamado arte. Compone grandes espacios en las paredes de los museos, donde, con su característico carácter poético, dispone de todo lo posible para contener un "reservorio" de memorias, que retiene en ese depósito, todo lo cargado del sentido de las expresiones visuales de nuestros días, gracias al talento de instalador. Es todo lo que él busca dentro de 
su personalidad, indumentaria creativa y encuadre estilístico; todo para darlo al espectador y compartir con él la poesía y significados de una noción de la historia del arte personal, la cual proviene tanto de sus vivencias cotidianas, como de sus andanzas por todo el mundo.

Imagen 1. Rolando Castellón. Betty Rymer Gallery, Chicago (1997)

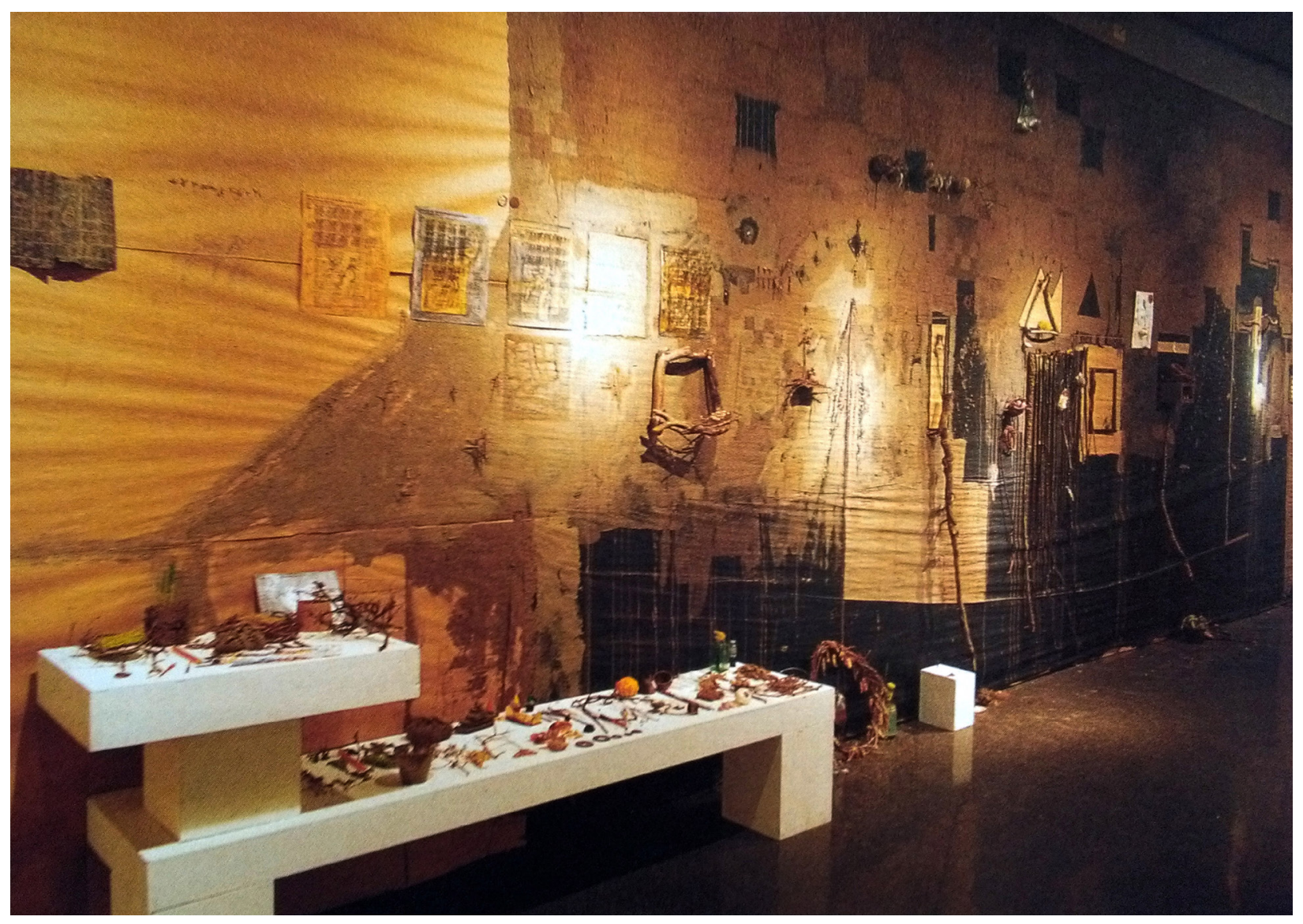

Fuente: Rolando Castellón.

Son vivencias del ayer, de hoy y que también lo serán mañana; son sus búsquedas más elementales. En tanto es quien recolecta lo que observa, se queda con una piedrita, con la cual quizás tropezó; o con un alambre corroído por la intemperie, que fue aplastado por el tránsito vehicular, en una vía de la barriada o de la ciudad, o porque quedó atorado en un resquicio de la acera, pero, cuyo signo está ahí, pues en sus manos de catador de 
materiales, es una verdadera joya. Lo cual, recuerda su instalación Joyas de Pobre (2011) expuesta en la 54 Bienal de Venecia, en la cual participó representando a su país de nacimiento, Nicaragua.

En este punto liminar, evoco otro pensamiento del emperador Adriano, respecto al verdadero lugar de nacimiento: ese sitio era el lugar donde, por primera vez, Adriano puso una mirada de conocimiento. Ese lugar eran los libros -lo aprendido-. Este aspecto denota la universalidad, en tanto que los grandes maestros no son de un lugar único, sino de muchos, donde han dejado anudados esos vestigios recolectados en sus andanzas y aprendieron, ya que el aprendizaje es constante, durante toda la vida. No se termina de ser de un sitio, siempre se hundirá el ombligo en nuevas tierras, respirando nuevos aires y catando otros pensamientos. En el caso de Castellón, su lugar de nacimiento fue en Managua, pero también Barrio México, San José, Costa Rica, así como San Francisco California y Oporto Portugal, este último dónde siempre reclama retornar, instigado por la luminosidad y los aromas salinos del mar.

\section{Noción del caos}

Cuando observo su obra y trato de indagar alguna explicación, para darle contenido a mis observaciones, comprendo la inmedible dimensión del caos, una dimensión que no es suya ni de nadie, le pertenece al Universo, donde él -Rolando Castellón, Moyo Coyatzin, Crus Alegría, E’Mundo Chevón, o cualquiera que sea el pseudónimo usado en una situación o momento- es un mediador. Sobre todo, siguiendo a los autores de Las Siete Leyes del Caos (1999) cuando definen el mediador como el "transgresor", a quien se le identifica con el portador y productor de la cultura: "es un chamán, superviviente astuto, travieso desvalido que desafía la convención, subvierte el sistema, rompe la estructura de poder y lo alumbra con nuevas ideas" (Briggs \& Peat ,1999, p 14).

\section{Cenizas, aguijones, rastros}

No puedo decir ni más ni menos de esas series de dibujos, collages, ensambles e instalaciones del viejo "Moyo Coyatzin" exhibidas en el MADC (2005), en la galería de la Universidad Véritas (2013), en el Museo Municipal de Cartago como parte de MAYINCA Cartografías (2014) y en MAYINCA (2015) bajo el título de Chunches de Tiquicia. Además, estuvo en el Museo Mexicano en San Francisco California 2016, en el Museo Nacional para la X Bienal 2016 y el Museo del Jade 2016.

Sus técnicas son los esgrafiados, los rasgados, raspados, punzados, cortados, relieves. Son gestos a los cuales agregará algo más: cuando los expone una y otra vez reelaboran el tema, subvierte dicho ordenamiento con la idea de reinventarlos, de encontrar un 
vórtice para desplazarse sobre las aguas del río del arte y, al emerger, engendrar otra cosa. Demostrar otra mirada, en tanto no es la única, hasta que dichas aguas encuentren una roca que las divida y, por la misma fricción, se evaporan y suben a las nubes, o mantendrán su incesante flujo que provocará una intensa acción, que lo llevará a algo que ni siquiera hubiese pasado por su mente. Sin embargo, llega, descubre, realiza y mira una vez más. Si no pasó por esas contingencias ni experimentó la carga de incertidumbres de la deriva del arte, no sería él ni ninguno de los personajes con los cuales se representa a la sociedad. Ese es el carácter de la práctica artística de quien recolecta y encuentra nuevas configuraciones, pero siempre dentro de lo genuino de un estilo: del universo, en el cual él pone su ojo y huellas.

Imagen 2. Rastros. Museo de Arte y Diseño Contemporáneo (2005)

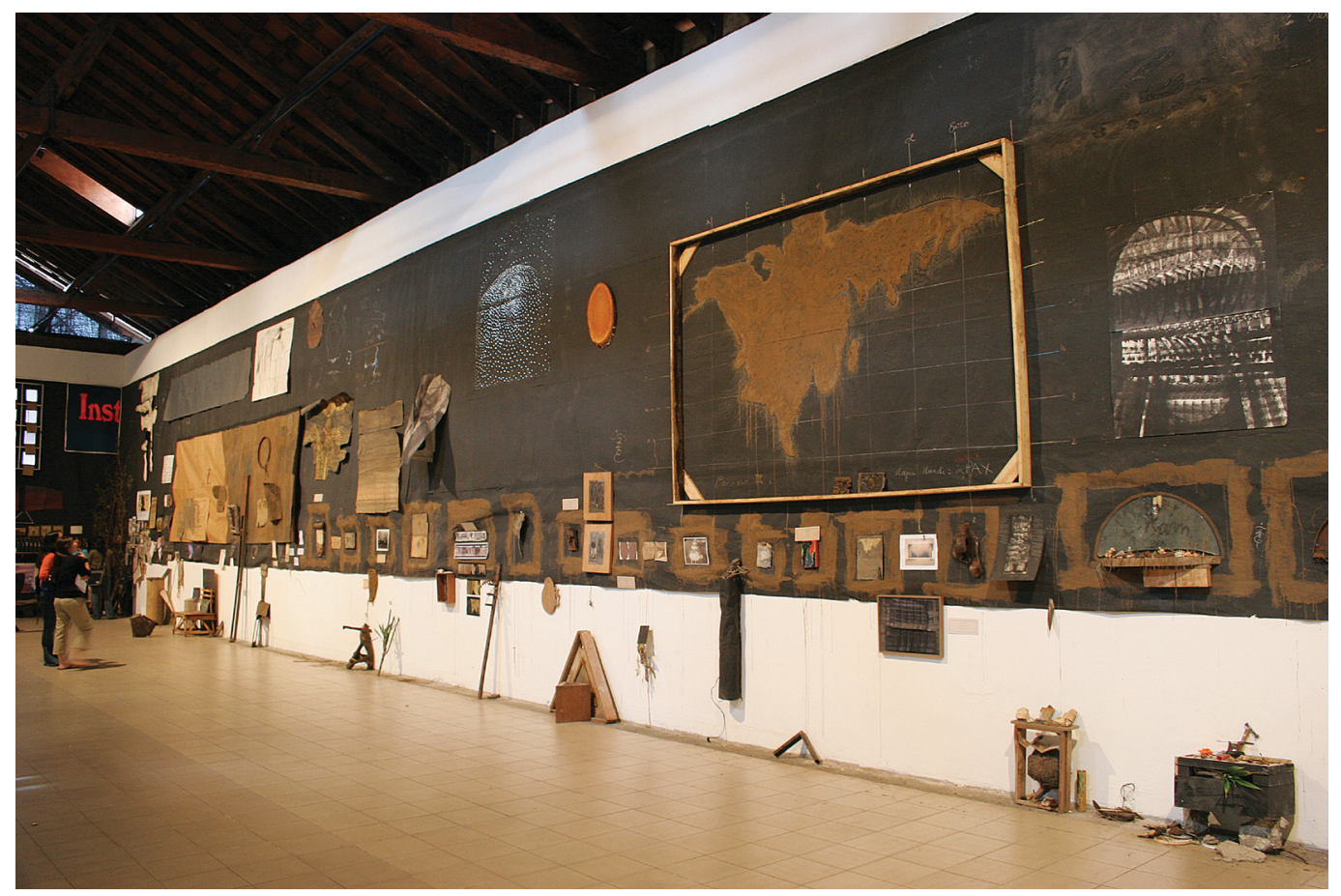

Fuente: José Alberto Hernández.

\section{Fluir en la deriva}

Cada mural creado por él es una "deriva" sinónimo de "laboratorio", donde se consume el artista a investigar, a formular teorías y encontrar rastros, indumentaria, técnicas y formas particulares de reconocer lo propio de su pensamiento, para saber de sí mismo 
encontrando explicación a las múltiples miradas. El laboratorio de arte define el significado de la práctica artística. El libro Coloquios del Diseño, publicado por la Especialización en Pedagogía del Diseño de la Universidad Nacional de Colombia, incluyó uno de mis ensayos que titulé Aprender. Compartir. Investigar. Premisas prácticas para una pedagogía del diseño, que también aplica al arte: la deriva se compone de capas. Cada búsqueda en ese laboratorio preña las capas con una acción de contenido, de expresión, de trazos, de espejos que revierten lo figurado en ellas y en el entorno. La labor creativa en el laboratorio busca superponer todas esas estratificaciones del problema para ver qué se transparenta entre ellas; se pregunta cuánta porosidad hay en la deriva y motiva a tratar de deducir hacia dónde se quiere ir, intuir hacia dónde fluye para seguirla, para no dejar su pista, para anudar lo especulado y sacar a flote la esencia de dicha investigación que siempre será el proceso.

La deriva, en tanto proceso, es un espacio en el que flota la creatividad. Entonces, el artista al ser sensible a las ideas las recoge, las anuda, las relaciona, las teje y entreteje para reproducirlas en términos de innovación; aunque, otros en su propio espacio de taller hayan captado lo mismo. Las ideas, como las miradas halladas en el laboratorio adquirirán el rigor, la manera de hacer, la técnica y el método de cada uno, por lo que, aunque sean las mismas, siempre serán distintas; como cada uno de nosotros en su aparato perceptor; en ese gran laboratorio de la sociedad total cada cual deja huellas distintas. En dicho laboratorio es factible conquistar éxitos, como también errar, sin embargo, es tan importante triunfar como equivocarse, pues del error se aprende y no debe considerarse -como en la educación de ayer- un acto reprensible, sino como experiencia valiosa del taller, entendido como aprendizaje donde se conquista y -a pesar de todo- donde se encuentran los tesoros.

Se manejan conceptos actuales como el de la incertidumbre, la espontaneidad, la transparencia, la porosidad, pues la deriva se compone por estratificaciones donde cada una es poseedora de su propia (in)formación. Esto superpone capas que son leídas en profundidad, lo cual genera nuevas relaciones o vínculos aleatorios, como los que se pueden suscitar al navegar en Internet. Por lo tanto, la deriva maneja altas dosis de fogosa incertidumbre con sus contingencias, pues nadie sabe hacia dónde va a dirigirse, tampoco se sabe cómo va a quedar dicha composición. Si se supiera, quizás entonces no sería una deriva, sería otra cosa porque perdería ese encanto cambiante y su carácter (trans)formante. Devoard -citado en el referido texto de Coloquios del Diseño- expresa: "el cambio más general que propone la deriva es la disminución constante de esos márgenes fronterizos, hasta su supresión completa" (Devoard, 1999 citado por Quirós, 2015, p. 141).

La deriva es una manifestación cercana a la teoría del caos y del pensamiento complejo. Es como una planta o rizoma que nadie sospecha a dónde va a dar un nuevo brote. El algoritmo o fractal, en su referencialidad genera otras lecturas que fluyen en sus nuevos 
componentes. En el proceso de crear en deriva, los resultados son siempre diversos, es suficiente con pasar de nivel, una capa o, incluso, ponerla en reverso, que su transparencia creará otras lecturas. Algo fundamental es que cada capa puede ser creada por diferentes individuos, por lo tanto, su combinación es producto de una acción colaborativa en interacción humana. Los murales de Rolando Castellón son mapas situacionales - muy cercanos a esta teoría-, cartografías del camino, mapeos mentales de sus conocimientos. Apreciar uno de esos murales arroja lo que él sabe, creencias y manifestaciones que van desde lo espiritual hasta lo sensual, cargado de erotismo.

\section{Las azarosas plegaturas del inconsciente}

Una de las aristas de ese compendio creativo -volviendo a la obra del maestro Castellón- es una serie de cartones doblados, plegados, rasgados, punzados, heridos, suturados y pintados con una espesa pátina de barro: su materia favorita en tanto lo remonta de nuevo a los orígenes -pues es polvo y es agua y, como dice aquel aforismo oriental, "en un grano de polvo está el planeta entero"-. Resume un encuentro de total tolerancia entre la materia origen y el soplo que simboliza el gesto máximo y sobrenatural, pero que el artista ensaya y es Dios quien le da el talento para dar ese hálito de gracia, que algunos identificamos como la sustancia del arte, la materia y su conducción, cuando somos sensibles y dispuestos a expresar. Los griegos, citados por Eugenio Trías en el Artista y la Ciudad, hablaban

Imagen 3. Rastros. Museo de Arte y Diseño Contemporáneo. 2005

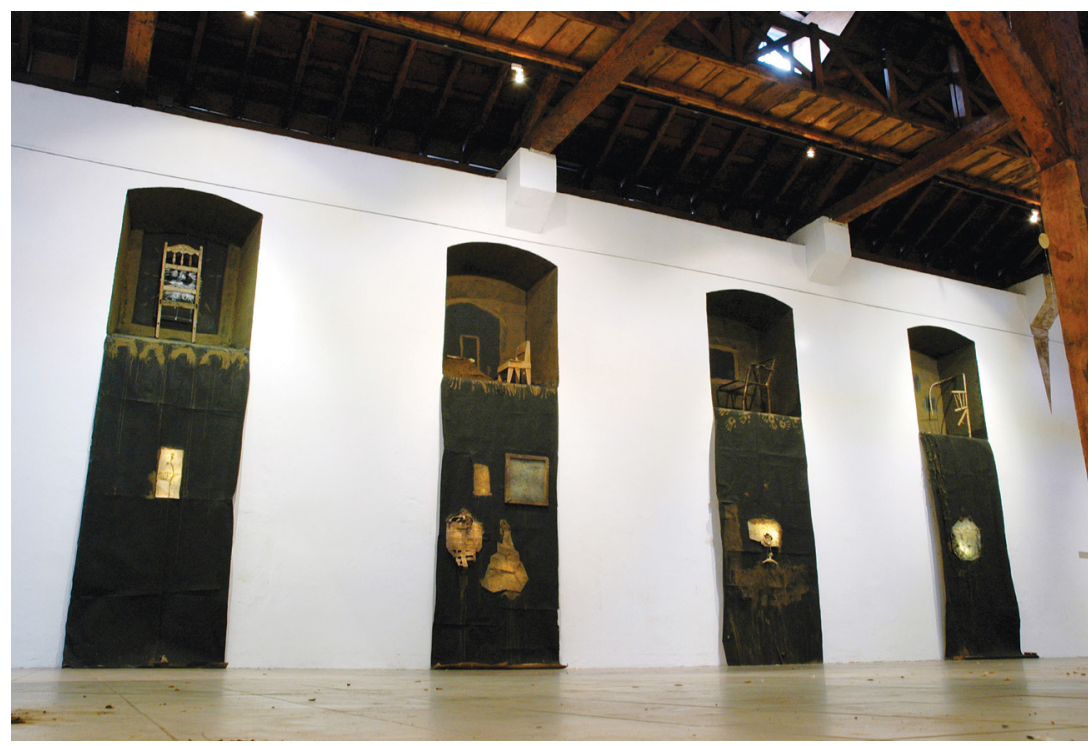

Fuente: José Alberto Hernández de ese grado de enamoramiento con la materia y con el objeto/ sujeto, como una forma de locura excelsa: a la que se llega a través de la reminiscencia de la belleza producida por algún objeto de este mundo con capacidad evocadora (Trías, 1998, p. 43).

\section{Deducción / comprobación}

En una zona de las dos salas del Museo Nacional, que 
fueron dedicadas a la retrospectiva de Castellón en la X Bienal 2016, se expuso una placa y la documentación relativa a la Primera Bienal Centroamericana, realizada el siglo anterior en el país, organizada por el Consejo Superior Universitario Centroamericano -CSUCA- en 1971. También se muestra una pieza facsímil de su dibujo "Danza aleatoria". Aquella primera bienal fue ganada por el arquitecto y artista guatemalteco Luis Díaz, con su obra Guatebala, la cual, al igual que la pieza de Castellón, fue borrada del mapa. Ambas desaparecieron en algún punto del itinerario expositivo por este istmo que, alguna vez, la desaparecida Virginia Pérez-Ratton llamó Estrecho Dudoso, uno de los proyectos expositivos más importantes curados en la región y título del libro con que TEORéTica: arte+pensamiento quiso eternizar las ideas y obra de esta gran mujer centroamericana.

Pero volviendo a la evocación de esta dinámica de Castellón, él fue el único quien recibió el premio correspondiente a cada país, por su representación de Nicaragua-cuando los demás premios incluyendo el de Costa Rica fueron declarados desiertos, encendiendo airadas protestas-. Traigo a colación estas memorias pues al exponerse esa placa y documentos de aquella "reminiscencia", vuelve a la luz y se devela en la "memoria", que parece tanto interesó a la organización de esta Décima Bienal y, por la cual, le fue concedido el Premio Nacional de Artes Visuales Francisco Amighetti 2016.

\section{Moyo Coyatzin, el emocional}

La posibilidad que he experimentado durante más de veinte años de conocer y seguir a este artista, hoy ya octogenario, me permite afirmar que él es un fiel escucha de sus propios pulsos, un conocedor de su métrica interior, del significado que su visión y su mirada infunden. Es capaz de interpretarlos, de seguir el hilo de los significados de esos latidos, es quien sabe reconocer su corazón. Se es creador en arte en el momento que se conoce a sí mismo, al tener conciencia de sus talentos y/o falencias. A eso también se le conoce como tener experiencia; ser portador de un bagaje intelectual, que puede incluso hasta ser prestado, pero que se sabe usar a partir de la razón propia. Aspecto que me recuerda el título de la novela de la italiana Susanna Tamaro Donde el corazón te lleve. Tiempo atrás, "corazón" era una palabra impronunciable en la literatura para no caer en lo cursi, hoy en día la recuperamos. Quiere decir que seremos capaces de atraer la mirada de los demás hacia nuestra obra, en la medida que sepamos reconocer las flores que brotan en nuestros jardines interiores. Por lo tanto, saber quién soy, cuál es mi indumentaria creativa: saber qué atuendos favorecen ese estado de ánimo expresivo y saber conducir día a día esa categoría de la investigación autoreferencial. El doctor Daniel Goleman, en el libro La inteligencia emocional, explica:

ESCENA. Revista de las artes, 2018, Vol. 78, Núm. 1 (julio-diciembre), pp. 196-222. ISSN 2215-4906 
Algunos de nosotros estamos naturalmente más en armonía con los estilos simbólicos especiales de la mente emocional: metáforas y símiles, junto con la poesía, las canciones y las fábulas, están representados en el lenguaje del corazón. Lo mismo ocurre con los sueños y los mitos, en los que las asociaciones libres determinan el flujo de la narrativa, acatando la lógica de la mente emocional. Quienes tienen una sintonía natural con la voz de su corazón -el lenguaje de la emoción-, están más seguros de ser expertos en la articulación de sus mensajes (Goleman, 2008, p. 76).

Imagen 4. Rastros. Museo de Arte y Diseño Contemporáneo (2005)

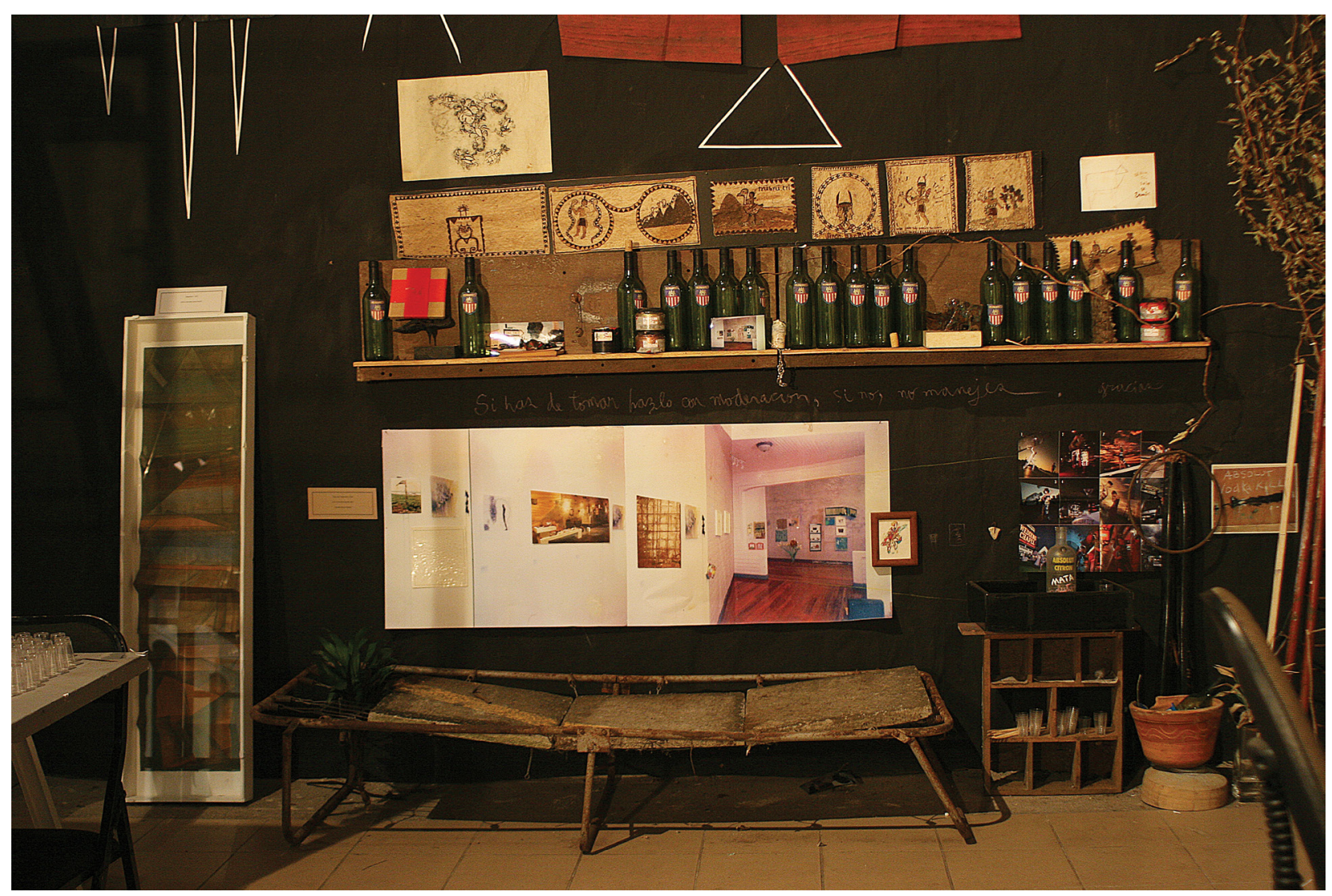

Fuente: Fuente: José Alberto Hernández 
Por su parte, el también estadounidense, Howard Garner observa el fenómeno tan propio de los individuos que mejor desarrollan la creatividad artística como una "inteligencia intrapersonal", al referirse a la facultad humana de comprender y saber controlar el ámbito interior de sí mismo. Los artistas son proclives a ahondar en la introspección -lo que yo llamo caminar- para comprender los razonamientos acerca de las contingencias que los afectan, lo que los teóricos llaman capacidad de autocomprensión. Pero, es importante observar el temperamento de estas personas altamente creativas, quienes poseen un afinado pensamiento crítico son, en suma, observadores, deductivos, analíticos, pero también incómodos. Si se pudiera caracterizar a estos individuos sería como traer una "piedrita en el zapato en el camino". Por lo general, son individuos que nadan contracorriente, difíciles de convencer, hasta que su juicio dé por anudado todos los aspectos del asunto o estudio, opinan. Respecto a este aspecto conductual, Goleman añade: "el temperamento puede ser definido en función del humor que tipifica nuestra vida emocional. En cierta medida, cada uno de nosotros posee una amplia gama emociona" (Goleman, 2008, p. 251).

Para este autor, desde nuestro nacimiento y por acción genética seremos difíciles o irritables, tímidos o serenos. Eso lo captan los padres durante el crecimiento. El autor agrega una pregunta central a este discurso: ¿dichos caracteres pueden ser cambiados por la experiencia? Pienso que el medio en que nos desarrollamos motiva a reconocer una sensibilidad hacia los materiales y los soportes. Castellón, por ejemplo, habla sobre cómo, durante su infancia, vivió en una casa de paredes de barro y un piso de tierra. Agrega que, cuando barría su abuela o sus tías tiraban agua a la tierra, al pasar la escoba hecha de hiervas peinaba aquel lodo y como a él le impresionaban los trazados remanentes. Además, las paredes poseían su propia pátina que aportaba a aquella memoria del lugar. Por un lado, su madre era costurera y hacía "cuilquens" hechos de retazos de telas que combinaba al azar, creando textiles de gran belleza que él aún conserva en su colección. Por otro lado, el fogón de la cocina ahumaba las paredes y maderas del techo; la misma composición de los utensilios colgados en clavos era una instalación. El crítico de arte español Aimar Arriola, en el blog CONCRETA, comenta: "el interés por lo orgánico, la poética de los materiales o el reconocer en el arte y la vida cierta vulnerabilidad ontológica, se encuentra de antemano en el trabajo de Rolando Castellón" (Arriola, 2016, penúltimo párrafo).

\section{La instalación en el arte contemporáneo}

En las últimas tres décadas del siglo pasado, los artistas visuales se sirvieron de un medio para manifestar su práctica artística: la instalación. Ese terreno fértil para la creatividad, en tanto maneja el espacio tridimensional y el bidimensional. En este entran en juego la luminosidad u otros valores del lenguaje, así como la tecnología que distingue las últimas 
tendencias. Atentos a estas posibilidades expresivas, dichos artistas no dejaron pasar la oportunidad para regenerar sus ideas en un arte contemporáneo caracterizado de profundamente cambiante.

\section{Remotos orígenes}

Pienso que el manejo del espacio, la incidencia de la luz en ese espacio, la convivencia de objetos que ahora llamamos "instalación". Ha estado presente en el arte desde los albores de la humanidad, relacionada a otros aspectos de la vida. Tanto en las manifestaciones funerarias de las culturas originarias como en los imperios agrarios de Egipto y Mesopotamia: la manera en cómo disponían al muerto con todos sus objetos de uso cotidiano, la espacialidad de la tumba y los materiales para su construcción, nos refieren a la idea que tenemos en la actualidad de la instalación. En la Sala de la Memoria del Museo de Jade y la Cultura Precolombina, se aprecia a cabalidad como nuestros ancestros originarios "empaquetaban" los restos mortuorios u osamentas: apreciable desde nuestra óptica del arte contemporáneo con los "empaquetajes" y la instalación.

Desde la perspectiva del arte histórico, en el Renacimiento se observó como Piero della Francesca identificó el sitio donde ubicaría los personajes de su pintura La Flagelación (lo que hoy llaman locación) en una terraza, al lado de la "Accademia Rafaello" (Escuela de Artes Gráficas) un edificio en la ciudad de Urbino, Italia. En el Barroco, artistas como Alberto Durero y el Caravaggio, antes de pintar el cuadro creaban una instalación utilizando objetos, telas, frutas, utensilios, con su respectivo efecto de la iluminación, lo cual poseía un lenguaje que luego trasladaba aquella "escenificación espacial" a la tela. Precisamente, lo que hoy en día denominados como bodegón o naturaleza muerta; experiencia creativa cuya forma llega hasta tiempos modernos. Son famosos, entre otros, los bodegones del también italiano Giorgio Morandi, quien se sirve de botellas y utensilios para manifestar su visión del arte en muy diversas técnicas artísticas.

La instalación como una forma de expresión visual, en la cual median los objetos, tuvo origen a inicios del siglo XX. Principalmente, se señala a Marcel Duchamp quien introdujo a la esfera del arte objetos cotidianos "resignificados", los cuales cambiaban su significado al darles una nueva disposición en el espacio y declarar una función como arte objeto. Recuérdese la famosa Fontana (1917), además de la Rueda de bicicleta subida sobre un taburete (1913) y el Portabotellas (1915-1923) exhibidos como ready mades en Nueva York, dentro de la tendencia denominada Dadaísmo o antiarte.

En el último tracto del siglo XX, se nombra a artistas como Helio Oiticica (1937-1980), Bruce Nauman (1941), Joseph Beuys (1921-1986), Claes Oldenburg (1929), Larry Bell (1939), Richard Wilson (1936), James Turrell (1943), Bill Viola (1951), Donald Judd (1928-1994), 
Christo (1935), entre otros. Se dice, además, que el precedente de la instalación son los environments o "ambientes" creados por el norteamericano Allan Kaprow (1927-2006) a partir del año 1957. Además de la Spiral Jetty (1970), considerada la obra más importante del estadounidense Robert Smithson (1938-1973) que acuña el término de earthwork o Land Art.

Imagen 5. Mural de la Retrospectiva. Museo Nacional de Costa Rica. 2016

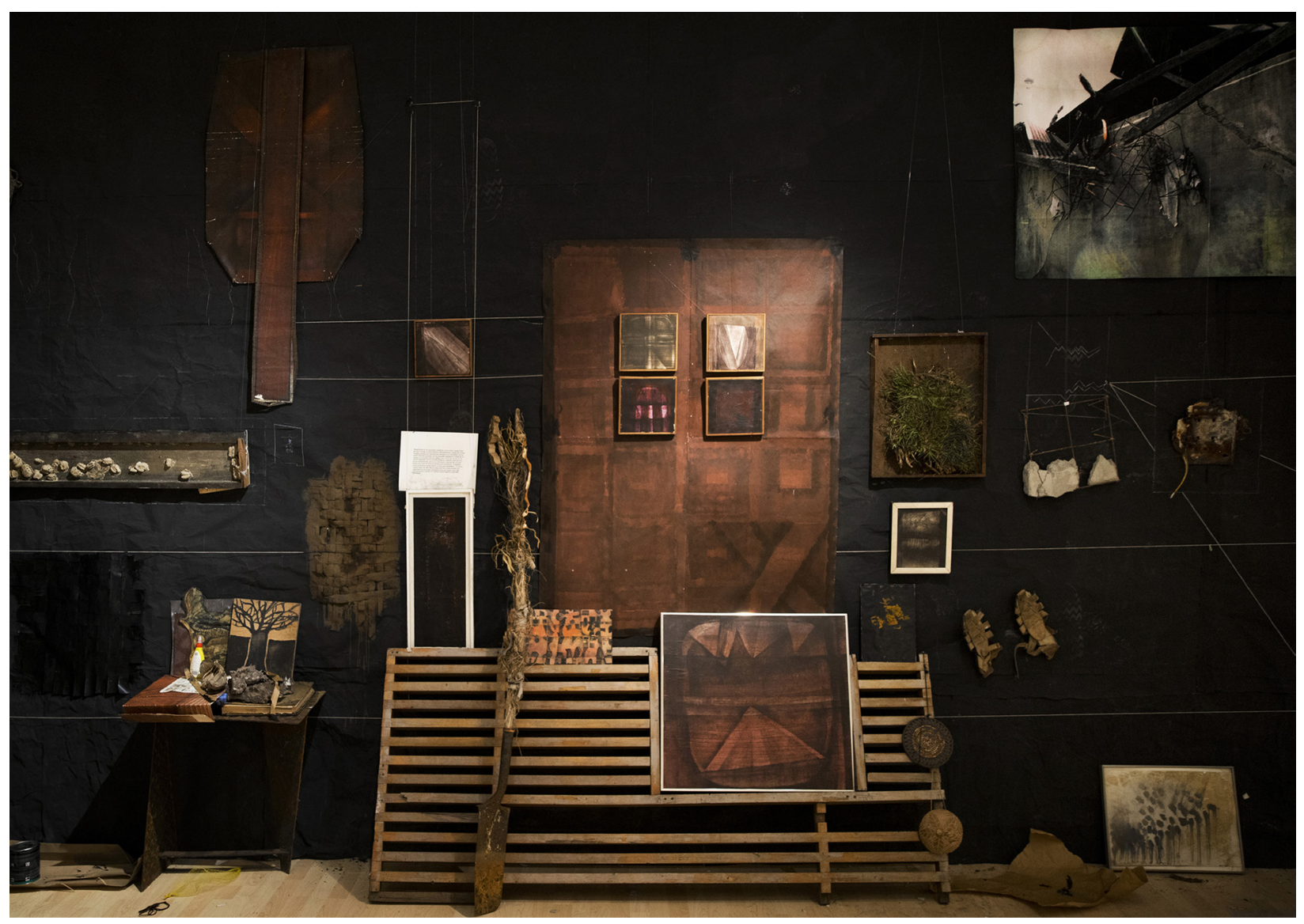

Fuente: Flavia Sánchez

En Costa Rica son reconocidos instaladores Rafael Ottón Solís (1946), Rolando Castellón (1937), Pedro Arrieta (1954-2004) y Joaquín Rodríguez del Paso (1961-2016). Arte que tomó fuerza luego de la creación, en 1994, del Museo de Arte y Diseño Contemporáneo (MADC), en el cual se expuso el proyecto Instalo-Mesótica (marzo-junio 1998). El 
evento contó con artistas nacionales e internacionales como Carlos Capelán (1948), Braco Dimitrijevic, Joscelyn Gardner, Suvan Geer, Florencio Gelabert, Marcos Lora Read, Cecilia Paredes, Fabrizio Plessi, Miguel Ángel Ríos, Joaquín Rodríguez del Paso, Soledad Sevilla, Rafael Ottón Solís, Otto Apuy, Robert Smithson (cortesía de John Weber) y la curaduría de Virginia Pérez-Ratton y Rolando Castellón, quienes llenaron los espacios del MADC, incluso, la Pila de la Melaza con sus ideas acerca de esta singular forma del arte de estos tiempos. En el plano internacional destacaron los "empaquetajes" de Christo, quien suele intervenir el paisaje, los edificios, los monumentos, cubriéndolos de telas para generar reflexión sobre la crisis del entorno en aspectos ambientales.

En las expresiones populares de nuestras culturas, las personas realizan instalaciones al hacer los "portales navideños", en tanto resuelven aspectos de espacio, utilización de variedad de objetos y se sirven de la iluminación como un recurso puntual, sin pretensiones de que sean arte. Es distinguible "instalar" en las zonas rurales costarricenses, en las cocinas de las casas antiguas con el fogón, la disposición de las ollas, la leña, el piso de tierra, las paredes ahumadas y forradas en papel periódico. Todas estas fueron manifestaciones vernáculas pintadas por Francisco Amighetti, Margarita Bertheau, Margarita Quesada, Jorge Gallardo, entre otros artistas del medio local.

Estas expresiones tienen que ver, de alguna manera, con el diseño del espacio interior, con el diseño ambiental, con la idea de la vitrina para clamar la atención del espectador, desde otras posturas creativas del mercado y la comercialización de productos. Aunque en el arte contemporáneo, difícilmente, se pueda acceder a vender una instalación porque estas son soluciones in situ y, pasado el evento para la cual fue creada, pierden valor. A no ser que se trate de una gran colección, o bien, los mismos museos que sí las coleccionan y las montan de forma temporal o permanente.

\section{El auge de los medios múltiples}

Las instalaciones se sirven de múltiples medios para crear una experiencia visual o conceptual en un ambiente o sitio específico del museo, galería, incluso al aire libre, como ideas del arte del paisaje (Land Art), o las intervenciones urbanas. En algunos casos, la instalación es transitable por el espectador y este va a ser componente temporal de la pieza, al generar una especie de acción en el lugar. Por lo general, se procura que el visitante interactúe, para regenerar esa idea, para que él tenga una memoria de su experiencia con la instalación. Todas estas vivencias se documentan anotando comentarios, tomando fotografías o videos que aportan una importante teoría al proyecto. Para la instalación, el artista se sirve de determinados recursos materiales, técnicos o tecnológicos que conjuguen con su idea, desde los naturales, hasta los multimedios: video, sonidos, computadoras, internet, 
sensores digitales, iluminación, láser, entre otros. Tal es el caso de la instalación Lo que nos dejó la marea (2016) de Diego Van der Laat y Pulse, en la muestra Conclusiones Actuales sobre el Arte Originario, del Museo del Jade.

Es necesario aclarar algunas situaciones contextuales dentro de las que se produce la obra de arte, las cuales modifican el soporte y la línea expresiva, como es el caso de la "instalación". En primer lugar, su carácter en sí, es decir, su multidisciplinariedad. En segundo lugar: observar cómo ese carácter del prefijo multi catalizan los inputs de transformación cultural y social actuales. El historiador de arte brasileño, Frederico De Morais dice que el arte no cambió de significado. Es una forma de profundizar el juicio del hombre, del mundo, de la sociedad. Puede que cambien las maneras de producirlo, los materiales, la forma de entablar comunicación, los estándares de presentación de la obra, pero el arte no va a cambiar.

\section{Multidisciplinariedad}

El arte de nuestros días es afín a otras formas de pluralismo, como lo multiétnico, multirracial y multicultural, cuyos paradigmas encuentran su punto de equilibrio en la singularidad y diversidad. La instalación se nutre con tramas de nuevos entornos: sonoros, visuales, sensoperceptivos y sinestésicos; con el uso de la música, el teatro, la pintura, la escultura, el diseño, la escenografía, la poesía, el cine, la televisión y, hoy en día, con la interactividad digital e internet. El rol del espectador es sustancial-comulga o es crítico a la vez- con el espíritu de la obra. En el arte histórico, el espectador era un actor pasivo; en el arte actual es un actor activo, coproductor con el artista de ese espíritu de la instalación. Otra característica del artista en la perspectiva presente es la singularidad de su lenguaje y su línea de expresión (producción, metodología y técnica). Además, su concepción de arte y el significado propio de su cultura, idiosincrasia y tradición. Pero, a su vez, esa singularidad adquiere valor en el multi-relacionarse (intrínseca y extrínsecamente) con el mundo. Su etnicidad, su credo, su ideología van a determinar la estructura de acceso y cómo será ubicado en esa amalgama que ahora se llama globalización en un sistema de relaciones múltiples.

Otro de los caracteres que impactan nuevos formatos y actuaciones de este arte es que el artista invita a otras personas a crear, en una acción, los componentes de la futura instalación. En la aludida muestra Conclusiones Actuales, la decana del Arte Conceptual en Costa Rica, Priscilla Monge, invitó al público a elaborar con arcilla -con la materia origenobjetos que evocasen el arte vernáculo, que luego fueron exhibidos en Los cabos sueltos (2016), a través del concepto de hacer partícipe al espectador en la creación de un arte. En similar situación se encuentra la pieza De las manos al polvo y del polvo a las manos (2016), del dúo formado por José Pablo Ureña y Adrián Flores Sancho, quienes se presentan como Materia Primera, de un perfil muy activo en la plástica nacional. Ellos invitaron a un considerable número de personas a ser partícipes de una acción en la cual hacían las huellas de 
sus manos. "Las manos [acotan los artistas en la ficha técnica] son el punto de partida para la captura de las huellas, las herramientas con las que se mide y se conoce lo táctil, son el espacio negativo de setenta voluntarios que reproducen el gesto de juntar las manos para beber agua, es la memoria milenaria en forma de reflejo".

Imagen 6. Sala del mural en la Retrospectiva, Rolando atendiendo a estudiantes. Museo Nacional de Costa Rica (2016)

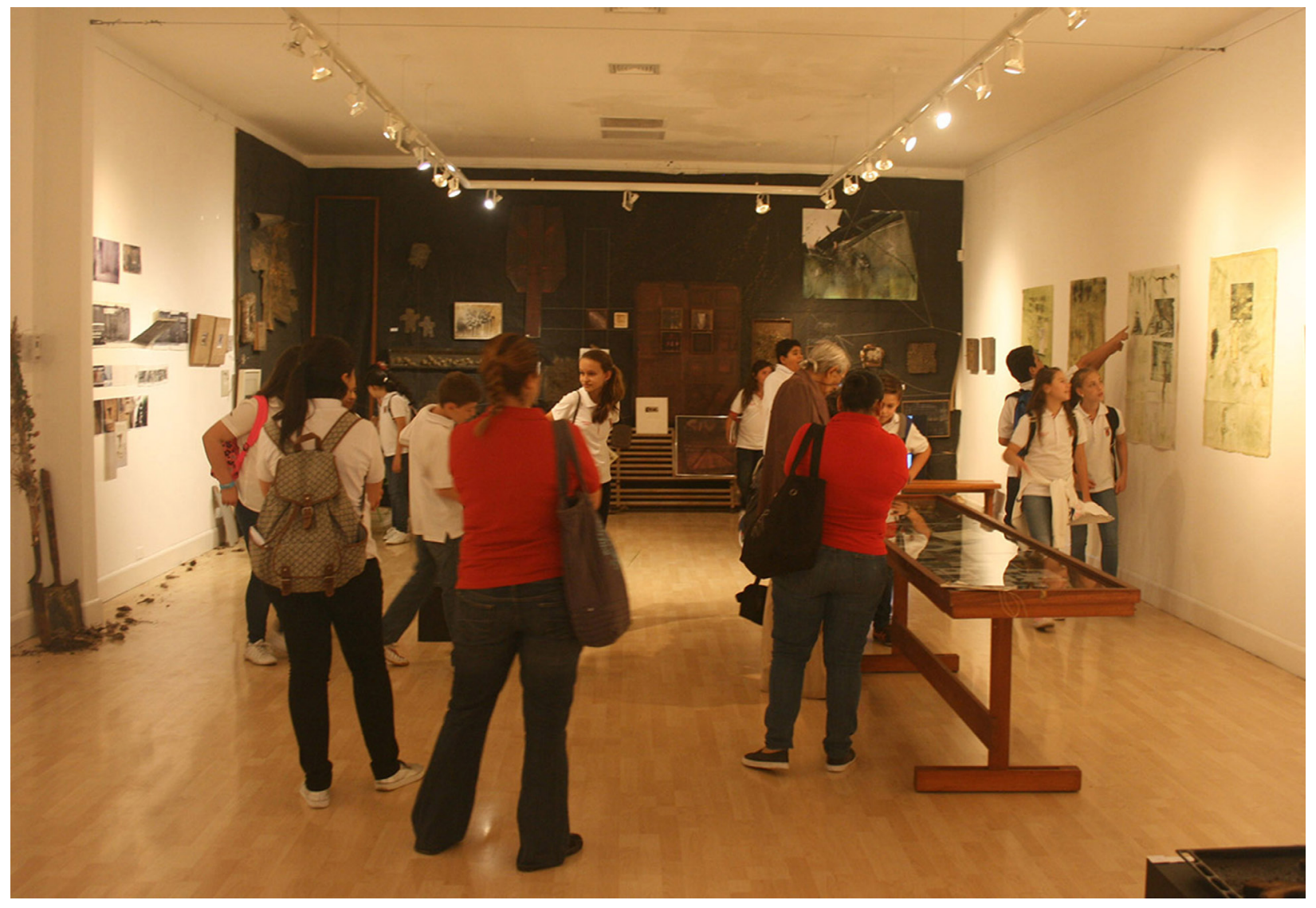

Fuente: Flavia Sánchez 


\section{Consideraciones prácticas para una instalación}

Es necesario, observar el espacio o sitio disponible para instalar; determinar dimensiones, niveles del piso, si el espacio o sitio a instalar es cerrado o abierto, considerar la iluminación, las corrientes del viento, la situación dentro del museo o la galería; la propuesta espacial puede ser central y que el espectador la recorra perimetralmente, o puede ser penetrable; considerar los materiales a disposición según una idea directriz, contenido y concepto. Todo material posee un lenguaje: si es liso, áspero, transparente, opaco, pesado, liviano, todos estos aspectos aportarán a la lectura de la pieza. Por tanto, es importante determinar el punto del observador, desde donde apreciará la pieza. Se planea, entonces, un recorrido, en caso de que la instalación pueda ser transitada. De esta forma, es necesario considerar qué sensaciones advertirá el espectador, qué contenidos va a asimilar a través del lenguaje de los materiales y los signos latentes. Es importante que el visitante se comporte como quien colecta, situación del mismo artista, para que la experiencia de visitar el museo sea recordable. La resignificación de objetos, materiales, o incluso, otras obras de arte. Este abordaje es muy interesante cuando se encuentra un objeto que se produjo con una función específica, pero el artista encuentra una nueva posibilidad expresiva. Ese carácter, también, puede aportar a una instalación, tal como se realiza en el llamado arte objetual.

Un artista, de alta vocación hacia esta forma de arte, como Rolando Castellón invita a otros artistas a ser componentes de su propuesta, suelen ser re-encadenados en una sintaxis propia, agregando diversidad, tensión interpretativa y ese carácter "multi", del que hablamos. Así, aporta mayor interés y estimula la memoria colectiva. Aunque en sus inicios tuvo un carácter efímero, en la actualidad, como ya se mencionó hay instalaciones permanentes en algunas colecciones y museos. Incluso, las hay en proceso, como cuando, durante el tiempo que permanece abierta la muestra, el artista va cambiando e introduciendo nuevos componentes.

\section{Metodología del artista}

Cuando el artista recibe la invitación de un curador para participar en un evento de arte contemporáneo, luego de saber sus planes y el por qué fue seleccionado, es fundamental que visite el museo o espacio. Esto con el fin de tomar fotografías, atender a los caracteres propios del sitio, para ir ideando, por medio de bocetos o maquetas, el desarrollo de las intenciones, enumerar las necesidades materiales, así como requerimientos de equipos, tecnología disponible, entre otros factores materiales y conceptuales. Existen artistas que realizan un pre-montaje en su taller, luego lo trasladan e instalan en el espacio asignado o, por lo menos, construyen una maqueta detallada, donde adelantan los imprevistos que se puedan presentar durante el montaje definitivo. 
Imagen 7. Muro de Memorias. Museo del Jade y la Cultura Precolombina, muestra Conclusiones Actuales sobre el Arte Originario (2016)

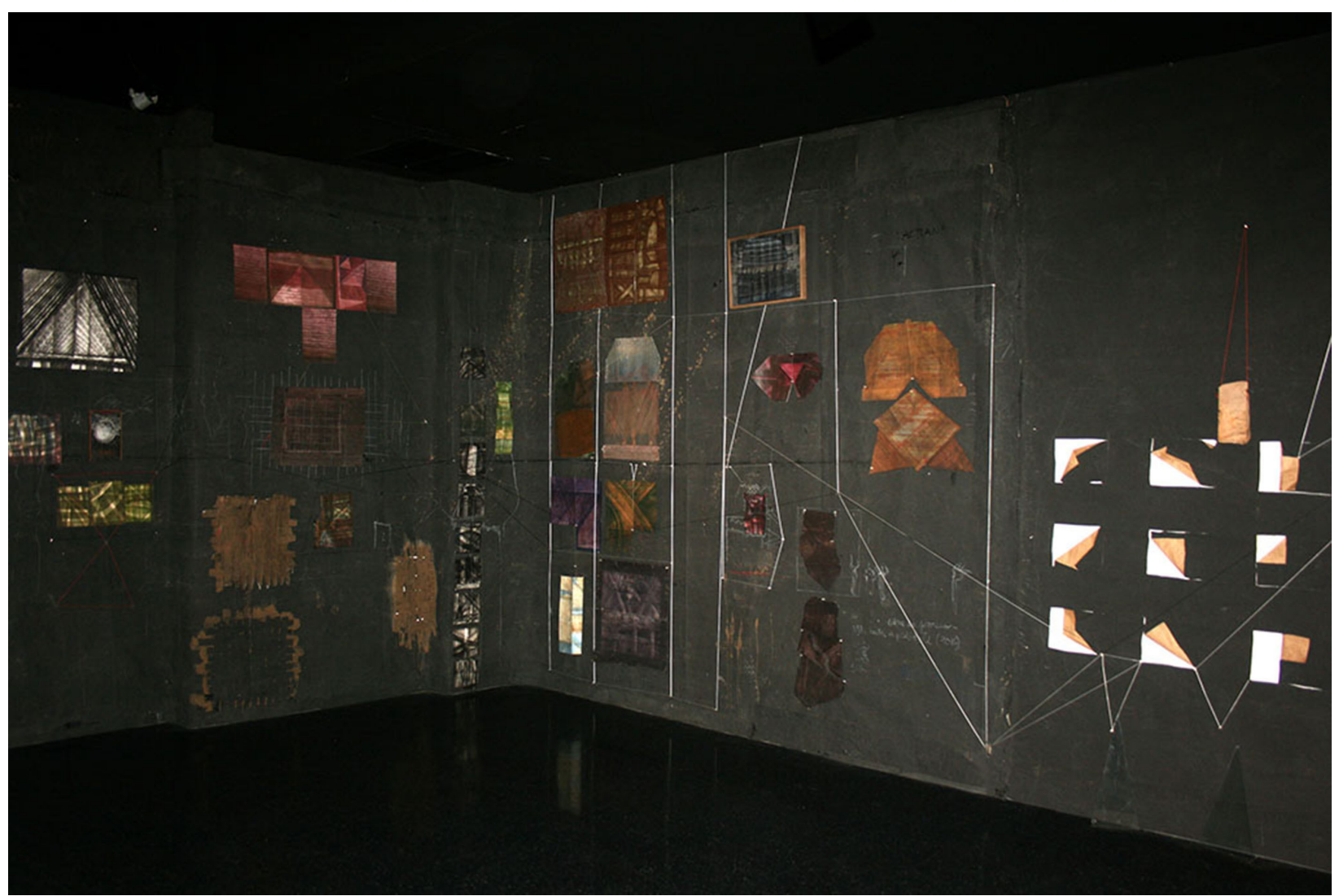

Fuente: Luis Fernando Quirós

Otros, al contrario, colectan materiales, objetos, imágenes y llegan al museo a empezar de cero, hasta ver concluida la idea. La experiencia del artista es imprescindible, solo él, con su astucia y aguda intuición, puede prever los resultados. Aunque siempre habrá incertidumbre, también es cierto que él es quien sabe manejar esas dosis del no saber, en tanto su creatividad y caracteres de innovación le permiten sacar provecho de las contingencias que suelen presentarse durante el desarrollo de la idea o instalación. 


\section{Conocer a Castellón}

Acercarse a él para conocerlo es un desafío complejo e intenso de asumir, ya que para observarlo se debe andar por todos sus caminos, por donde día a día anda sus recodos, atajos, encrucijadas, topografías y cartografías de una ruta que experimenta constantemente. Para saber de él -comenté en mi blog de la revista española Experimenta- hay que explorar y conocer la diversidad de ángulos de visión y del hacer arte hoy: él es el más genuino instalador que conozco. Además -como lo afirmó Paulo Herkenhoff-, el mejor dibujante de nuestra América, también se distingue por sus ideas de diseño y agudo pensamiento contemporáneo.

Si quisiéramos saber cuáles son las culturas o quiénes son otros artistas que él admira, diría que deberíamos hablar primero de la Mesoamérica Maya, del Inca y del Chorotega por su amor al barro. Pero, también, pienso que lo conmovió, en algún momento de su vida, el uso de los materiales de artistas como Antonio Tapies, Janis Kounellis, Mario Merz. En el texto de catálogo de la muestra Rastros (2005) en Sala I del MADC, Herkenhoff acota:

El arte de Castellón implica constituir una política de los materiales y constituir una economía simbólica más que una gramática canónica. Tal vez una lista de los materiales más importantes para Castellón, alejado el criterio de los más frecuentes y especiales, simplemente podría ser todo. No obstante, el artista tiene sus criterios de selección de los materiales: el despojo, el sentido povera y lo histórico, lo orgánico y lo natural, pero también la armonía visual, su potencia conceptual y la integración en el contexto físico (Herkenhoff, 2007, p. 19).

Virginia Pérez-Ratton, además, dijo sobre Rolando: "su arte empieza donde la naturaleza cierra su ciclo de vida, es una especie de "arqueología natural" que se sirve de ella como fuente de materiales de trabajo, pero hacia la cual mantiene una permanente actitud de reverencia (Pérez-Ratton, 2007, p. 80). Respecto a la inclinación de Rolando para crear instalaciones-murales, Pérez-Ratton señaló:

Muchas de estas instalaciones usan barro, lodo, sobre una superficie de soporte de papel kraft, directamente aplicado a la pared o en ocasiones como objetos independientes, que se convierten en su mismo soporte, agregando capas y más capas de lodo, integrando elementos en los que pareciera ser una disposición aleatoria, pero que de hecho refleja el caos armónico de la naturaleza (Pérez-Ratton, 2007, pp.80-81)

\section{Habitante de donde no se sabe}

Se vuelve difícil, como comenté, ubicar su procedencia. Nació en Nicaragua, pero él es de todas partes: de Costa Rica, Portugal, España, Japón, ciudadano de Estados Unidos. Castellón es de ahí donde exista el barro, cuerdas, semillas, ramajes, espinas, maderas y cartones, el pochote, la ceiba, el poró. Pero, también, necesita del agua, el aire, el fuego y 
nada sería sin su humor negro y su disposición hacia el juego. Es de la materia, su materia y, como los antepasados mayas, su corazón se vuelve cuenco de arcilla que rebasa de poesía, amor, sensibilidad, sensorialidad y capacidad de sorprenderse y sorprendernos por esas visiones tan genuinas. Castellón afirma que es centroamericano, punto. Es de este istmo, con sus historias de hombres de maíz, de volcanes y ríos, de selvas y escabrosas praderas que cada año azota el huracán y arrecian las aguas desenfrenadas de su condición geopolítica e histórica.

Un día de tantos me contó que fue invitado a la Bienal de Arte de Uruguay, pues en una de las ediciones de la Bienal de Venecia, alguien escribió que él era uruguayo. Además, alistó maletas para disfrutar de una residencia en Siena, Italia, quizás para andar por esas colinas con sus casonas añosas al lado de olmos y encinas, con sus torres medievales como estandartes que lo sitúan en el mundo que ama y hace suyo, por tanto, él es ciudadano del planeta.

\section{Curador, artista, creador de espacios}

Castellón posee su estudio principal en Zapote, San José. A la vez, este es su propio museo, donde realiza una muestra de su colección de arte contemporáneo, ARTEUM. Mismo concepto que, en la década de 1980, desarrolló en San Francisco, California y puso en la mira del acontecer a importantes artistas hispanos, chicanos y norteamericanos. Hoy exhibe a algunos de ellos, como parte de su enorme colección instalada con un diseño museográfico, también de un orden muy propio. También abrió el espacio ARTSeum La Garita, donde exhibe lo más cercano a la naturaleza, que brota en la misma muestra, a la que se le suben las hormigas y comen las termitas transformándose constantemente.

En la visita a uno de estos espacios, hablamos de muchas cosas, entre otras, de los tiempos en que trabajamos juntos en el MADC. Hablamos de Mesótica II Centroamérica/regeneración, itinerante por varios lugares europeas, entre ellas Madrid, París, Roma, Turín y Holanda. No estuvo al margen de la conversación, su estadía en la Costa Oeste de los Estados Unidos, cuando fue curador del Museo de Arte Moderno de San Francisco, director de La Galería La Raza y la Mary Porter Sesnon Art Gallery, de la Universidad de California, en Santa Cruz. Entre tantas otras intervenciones donde forjó esa visión de un arte contemporáneo fogoso, que conceptualiza todo: el espacio, el entorno, la luz, las texturas, los materiales; un arte hecho y mostrado con sencillez, de función lúdica, con alta dosis de desenfado, pero que cuestiona y clava la espina de la interrogante ante los grandes asuntos del existir o ante la incomodidad para con el mismo sistema del arte. 


\section{El disenso castelloniano}

El cuestionamiento de Rolando Castellón va más allá del arte, ya que critica la manera en cómo son comercializados los frutos de nuestra tierra: el maíz (Monsanto), el banano (United Fruit Company), el café, las verduras, las semillas, la comida, todo tiene que moverse con sigilo ante el oscilar de los intrincados mercados internacionales, aun somos vistos como "bananas republic". De ahí, el concepto de la instalación con que la participó en la $54^{\circ}$ Bienal de Venecia (2011) en el Pabellón del Instituto Italo-Latinoamericano (IILA) en el Arsenal. La muestra fue titulada Entre siempre y jamás. Ahí expuso la instalación Joyas de pobres, con objetos adquiridos o encontrados en el comercio informal de la calle, con alambres retorcidos, latas aplastadas, resortes y otros en una postura cruda, real, ardiente para decir que, en esos rudimentos del pobre, se congracia cierta dosis de belleza cuando el artista la encuentra, ahí donde quizás no la hay. Sin embargo, es suficiente que pase por su pensamiento de entendido para que lo sea. Si a nuestros antepasados prehispánicos, los europeos los sedujeron con baratijas y espejitos, el signo o garfio del arte se les devuelve como el antojadizo boomerang. Castellón ama sus materiales: dinero de pobres, barro, alambres, latas retorcidas, objetos encontrados, textiles deshilachados, herrumbre, critica las economías corruptas y usureras. Elabora su materia a partir del entorno del hombre pobre que hace sus manufacturas para sobrevivir.

\section{Posible diálogo sobre lo in/probable}

A mi pregunta ¿De dónde viene la obra de arte? Él, de inmediato, y colmado de esa fuerza emotiva que lo mueve, responde: -iDel corazón!- ¡Síl, le dije, y tú, Rolando, ¿si tú tienes el corazón de barro? Entonces, profundo, como es él, agrega: -viene de la música, de la misma locura, del aire, del viento, pero jmi corazón es un árbol!-.

Hablamos del arte, de las sensaciones, de lo emocional, de las situaciones que encuentra en su andar cotidiano mirando y colectando rastros de su existencia, que nos recuerda su importante muestra en el MADC, Rastros (2005). Porque el mundo es como una pantalla, donde se van sucediendo las imágenes de una película sin fin, de un continuum donde todo parece hecho, pero está por hacer. Si viéramos todo hecho, vana sería nuestra experiencia de estar en el mundo. Su arte es trenzar; ahora trenza los árboles de su jardín, entre su misma especie, que según dice, nacieron solos ahí en ese universo de la naturaleza, pues, nunca los sembró. También, los anuda entre diferentes especies, sin importar si son árboles, arbustos, plantas ornamentales o raíces que encontró por ahí. -¡Somos una semilla que se expande!- me dice mientras me ofrece un té de unas hiervas, con el sabor de tres tipos distintos de limones, que explica, provienen de su huerto. 
Imagen 8. Joyas de Pobre. Bienal de Venecia (2011)

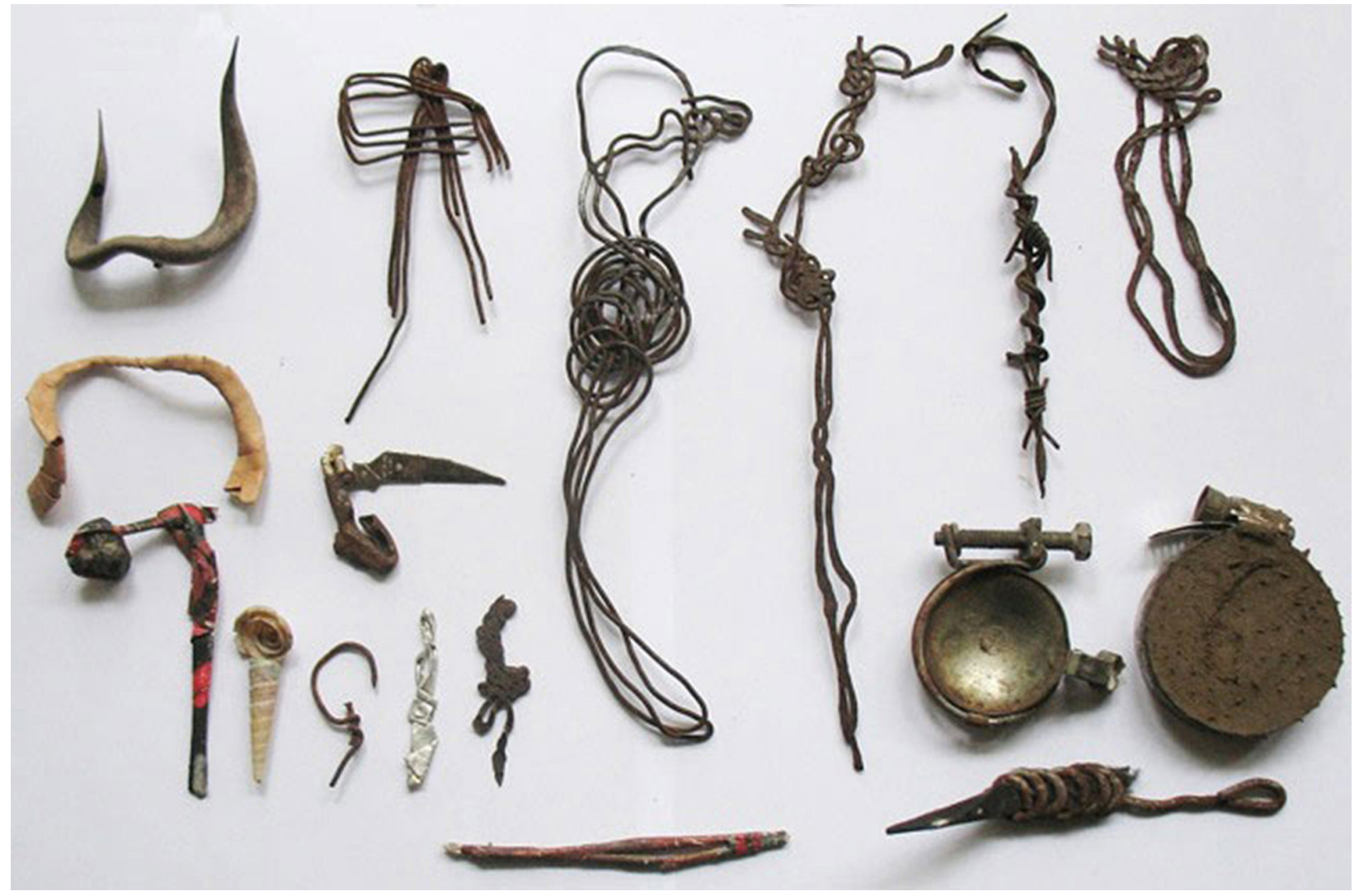

Fuente: Rolando Castellón

Le interesan los nudos, las cenizas, las espinas, los números, los tejidos, la poesía, los conceptos, las ideas, los catálogos, libros, revistas, postales, tarjetas, entre otros. E suyo es un arte de encadenamientos, de pensamientos, que se reinventan a cada paso, como dije, a la deriva. Es seguidor de las hipótesis de la numerología: dice que al 2012, lo sucede, inmediatamente, el 2013. Vivimos un flujo de un tiempo de renovación de la cultura, donde todos saldremos airosos y renovados. Hablamos, además, del arte que nos es arte y nos propusimos como meta crear una revista, proponiendo situaciones que, no siendo arte, se vuelven, ya que la situación ejerce fuerza y lo hace, al tiempo que nos hace, como aquel grabado de Escher de la mano que se dibuja a sí misma. 


\section{El artista, comentarista y crítico del presente}

-Tengo el corazón de árbol- me dijo -y mi cuerpo tiene espinas como el pochote, como la ceiba, como el poró-. No existe árbol sin tierra, no vive sin agua, sin aire. El agua, aunque es agua, se seca y se quema. Te lo demuestro - dijo y se fue a algún sitio de su taller. Olvidó que me había ofrecido un té y había puesto el agua al fuego, que se secó. El agua también se quema, repitió. Trajo el cuenco de metal, donde antes hervía el líquido para mostrarme las figuras que quedan en el fondo. Me dijo que él no los lava, para mantener el hermoso grabado en el fondo del utensilio. -Yo de niño -relata- tenía un pedazo de pared en la casa de mi abuela destinado a mis pinturas, a hacer mis murales-. Solo en ese espacio de la pared, podía rayar, pintar, hacer lo que quisiere. Además, tenía todo el piso de la casa, pues era de tierra. Abuela lo barría con una escoba de hierbas y ramas, luego yo dibujaba en él, con el palo de la escoba luego de tirarle agua para convertirlo en lodo.

Imagen 9. Escrituras. Detalle de mural Rastros (2005)

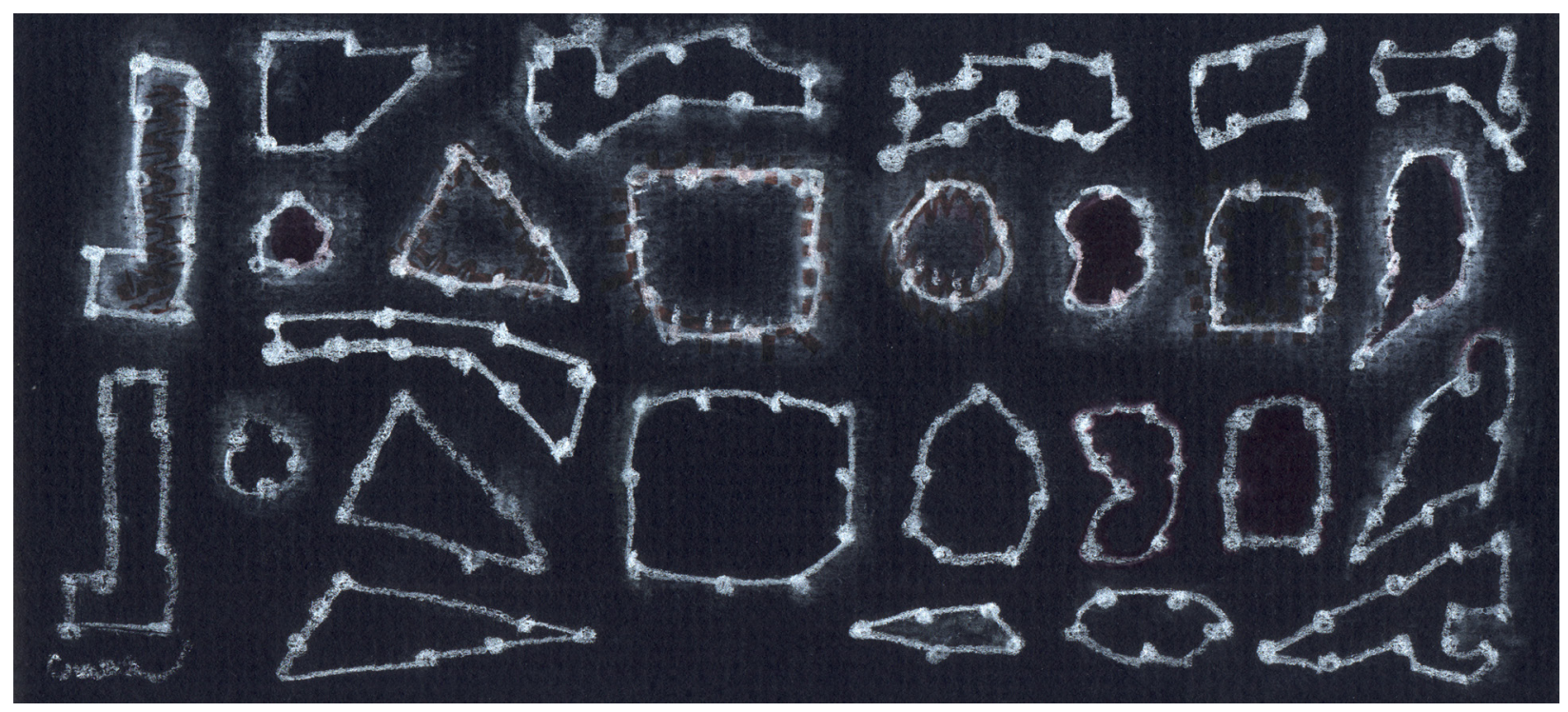

Fuente: Luis Fernando Quirós

Agregaba cenizas, tiznes, espinas de pochote, ramitas, piedritas, doblaba cartones y esa era mi pintura, como las joyas de pobre con que participé en Venecia. En el mismo pabellón de la Bienal, también participó Regina José Galindo, de Guatemala, con las calzas 
de oro que sacó de sus dientes, las usó como otro carácter de joyas instaladas sobre un fieltro en una vitrina. Al lado suyo, exponía su obra -similar, por cierto, y también con los dientes recogidos en una clínica de dentista- el hondureño Adán Vallecillo. Andábamos en lo mismo, quizás por eso nos juntaron en las páginas de los catálogos de la Bienal, y de otro libro que se publicó por ahí, y en artículos publicados en internet. Quizás con el signo de lo que se devuelve y golpea si no se sabe cómo sujetar.

\section{Rolando Castellón: coleccionar}

Nadie colecciona un objeto que no colectó, ni es catador de aquello que no tiene entre manos, mirada o pensamiento. Se trata de probar una fruta, un café, un pan, un objeto encontrado por ahí, o una pintura, un dibujo, un trozo de madera, una cerámica rota. La razón está en la sensibilidad y experiencia de quien lo hace, al descubrir caracteres que, para los demás, pasan desapercibidos. Se trata de experiencia y saber, pues nadie descubre aquello de lo que no tiene experiencia -aunque sea una vaga pista- y un deseo ferviente de poseerlo. Ya había usado esa figura literaria de Adriano antes, al hablar del maestro, Rolando Castellón (es más, cada vez que lo evoco a él en mis recuerdos surge la imagen de aquel conquistador de la Britania, La Galia, Egipto, entre otros lugares que empoderaron al Imperio Romano). Con Castellón -viajero y conocedor de las culturas del mundo- tuve una entrevista, es un acérrimo colector de lo que encuentra en los recodos del camino, aquello que, entre sus manos y visión del arte actual, impacta, ya que él sabe cómo valorarlo y exhibirlo. En su creación artística personal, es capaz de hacer con esos rastros un juego para nuestras emociones, al percatarnos de que aquel trozo de madera u objeto que, nadie imagina donde recogió, se regenere en otra condición material o de la forma, se reinvente ante nuestra propia mirada, motivada por el placer de observarlo.

\section{Pensamiento de una situación cambiante}

Después de participar en la primera gran muestra de Arte de Iberoaméricano en Madrid (1979), se trasladó a los Estados Unidos para ser uno de los artistas regionales más destacados en el arte contemporáneo. Reside en Costa Rica, desde 1993, hasta la fecha, y crea lo que transparenta ese dominio; multiplica las ideas en una meseta infinita, como el universo, sin fin. Ahí brotan, donde y cuando nadie las espera, son como el césped que uno observa y parece una única planta. Sin embargo, son muchas plantas entretejidas que ejemplifican la visión -natural y actual- de la Teoría de la Complejidad que significa elaborar una amplia diversidad de los sistemas, a partir de la visión de globalidad y del profundo Caos. 


\section{Intervenciones al paisaje urbano}

Otro de los aspectos que me sorprendió al observar la muestra de ARTSeum Zapote es que encontré libros de arte suyos, donde aplica su visión multiplicadora y regeneradora del paisaje. Con esa destreza de intervenir fotografías tomadas por él, creando enormes torres de arquitecturas, que solo están en su mente y pensamiento, donde los edificios virtuales se entretejen con los árboles, en una atmósfera biótica de perfecta armonía, para un diseño urbano tolerante. Tal y como debe ser, donde el habitante convive con la naturaleza y su entorno construido.

Imagen 10. Cactus. Detalle de mural (2005)

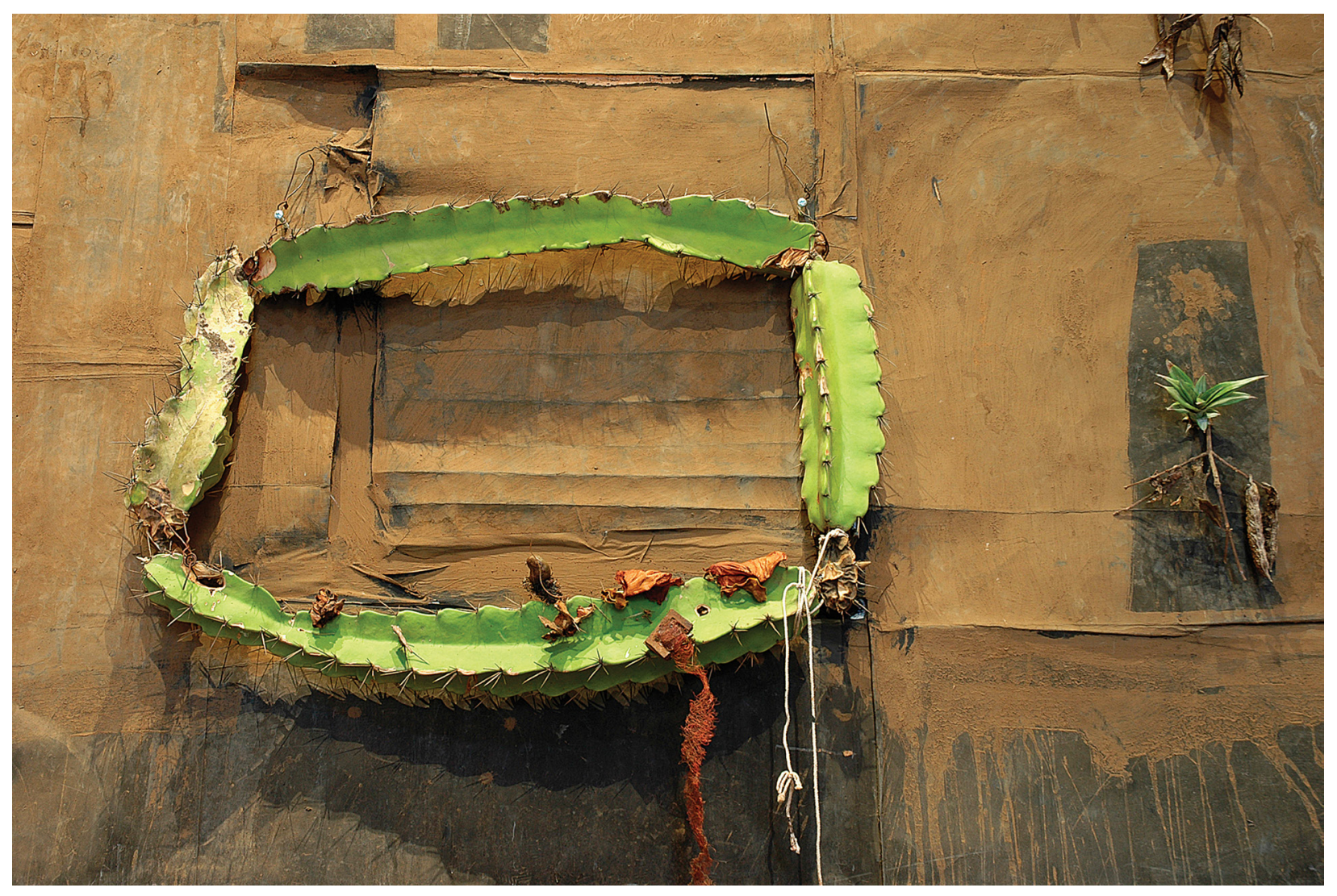

Fuente: José Alberto Hernández 


\section{Y, a manera de conclusión}

No puede haber un acercamiento a un maestro sin análisis de su obra y pensamiento, la crítica de lo apreciado, y sin que, también, exista una deducción final de lo aprendido. Este caminar junto a él inicia con la colecta de esos rastros de lo que encontró, repito, en su caminar por los bordes porosos de sus imaginarios; creatividad y genuino uso del lenguaje artístico; aquello que se puso delante de su mirada regeneradora. Lo que está entre la retina y la mácula del ojo, que le pertenece a él, y si no es suyo, se lo apropia con la magia que le caracteriza. Es un todo complejo, tejido en la amplia diversidad de puntos o tensiones interpretativas y subjetivas que él cuelga a su memoria personal, para luego, compartirlo en un libro, en un cuaderno o bitácora, en un ensamble o empaquetaje, dedicado a "todo lo posible", cuyos pivotes son el pensamiento. Ya para terminar, le pido prestado a Tamara Díaz Bringas un fragmento de uno de sus textos, donde leemos muchas más facetas de la existencia de un maestro que siempre nos sorprende con algo más:

Rolando era proyeccionista y "editaba" -cortaba y volvía a pegar- las películas para compartir diminutos cuadros sensuales con los amigos. Nunca aquellos jóvenes managüenses Roxana Podesta, Gina Lollobrigida o Silvana Mangano estuvieron tan cerca: en la generosa palma de la mano, como quien dice. Por eso, cuando mucho después viera Cinema Paradiso, Rolando pensó que el guion de Tornatore era casi una repetición de sus vivencias (Díaz-Bringas, 2007, párr. 4).

\section{Referencias}

Arriola, A. (13 de diciembre del 2016). Ojos táctiles, ojos blandos, tercer ojo: una mirada compuesta a la X Bienal Centroamericana. CONCRETA [Entrada de blog]. Recuperado de http://editorialconcreta.org/ojos-tactiles-ojos-blandos-tercer-ojo

Briggs, J. \& Peat, D. (1999). Las Siete Leyes del Caos. Barcelona: Grijalbo-Mondadori.

Díaz-Bringas, T. (9 de octubre de 2007). La verdadera historia de un personaje ficticio; o la historia ficticia de un personaje real [Entrada de blog]. Recuperado de https://textoserrantes.wordpress.com/2007/10/09/90/

Pérez-Ratton, V. (2007). Rolando: Artista, Jardinero y Curador Picaflor. San José: Teorética.

Quirós, L. F. (19 de marzo del 2012). Rolando Castellón. Coleccionar [Entrada de blog]. Recuperado de https://www.experimenta.es/blog/luis-fernando-quiros/ rolando-castellon-coleccionar-3443/

Quirós, L. F. (30 de enero de 2012). Rolando Castellón. Acercamientos [Entrada de blog]. Recuperado de https://www.experimenta.es/blog/luis-fernando-quiros/ rolando-castellon-acercamientos-3363/ 
Trías, E. (1997). El Artista y la ciudad. Barcelona: Editorial Anagrama.

Yourcenar, M. (2003) Memorias de Adriano (trad. J. Cortázar). Buenos Aires: Editorial Sudamericana. 